\title{
Rice arbuscular mycorrhiza as a tool to study the molecular mechanisms of fungal symbiosis and a potential target to increase productivity
}

Tomomi Nakagawa ${ }^{1,2}$ and Haruko Imaizumi-Anraku ${ }^{3^{*}}$

\begin{abstract}
Rice (Oryza sativa L.) is a monocot model crop for cereal molecular biology. Following the emergence of molecular genetics of arbuscular mycorrhizal (AM) symbiosis in model legumes in the 1990s, studies on rice genetic resources have considerably contributed to our understanding of the molecular mechanisms and evolution of root intracellular symbioses.

In this review, we trace the history of these studies and suggest the potential utility of AM symbiosis for improvement in rice productivity.
\end{abstract}

Keywords: Arbuscular mycorrhizal (AM) symbiosis, Phosphate transporter, Common symbiosis pathway (CSP), Mycorrhizal (Myc) factors, Lysine motif (LysM) receptor-like kinases, Strigolactones (SLs)

\section{Introduction}

Arbuscular mycorrhizal (AM) symbiosis is an ancient endosymbiosis that originated more than 400 million years ago (Remy et al. 1994). Most land plants engage in a cooperative relationship with obligate biotrophic fungi of the phylum Glomeromycota. Strigolactones (SLs) secreted by plant roots into the rhizosphere act as branching factors for AM fungal hyphae (Akiyama et al. 2005). Fungal exudates induce symbiotic $\mathrm{Ca}^{2+}$ spiking in the host cells, which is crucial for AM fungal infection. AM fungi penetrate the root epidermis through hyphopodia. The pre-penetration apparatus (PPA), an intracellular pre-infection structure, is formed in the host cells to determine the penetration path of fungal hypha from the epidermis to the cortex (Genre et al. 2005, Oldroyd 2013, Recorbet et al. 2013). A highly branched hyphal structure, an arbuscule, develops in the cortical cells and serves for nutrient exchange between the host plant (which provides photosynthates) and the AM fungus (which provides mainly phosphate along with other

\footnotetext{
* Correspondence: onko@affrc.go.jp

${ }^{3}$ Division of Plant Sicences, National Institute of Agrobiological Sciences,

2-1-2 Kannon-dai, Tsukuba, Ibaraki 305-8602, Japan

Full list of author information is available at the end of the article
}

nutrients). External hyphae growing from the mycorrhizal roots allow host plants to assimilate phosphate from outside the root zone (Fig. 1) and therefore to survive in phosphorus-deficient soils.

\section{Review}

Identification of AM-specific phosphate transporters

Identification of AM-specific phosphate transporters was the starting point of molecular genetic research on AM symbiosis in rice. Using genome-wide data for rice (Oryza sativa L.), Paszkowski and colleagues have identified 13 phosphate transporter genes $(P T)$ and determined that OsPT11 is specific to AM symbiosis (Paszkowski et al. 2002). The OsPT11-GFP fusion protein is specifically localized in the periarbuscular membrane surrounding young and mature arbuscules, where active phosphate transfer seems to occur (Kobae and Hata 2010). Using OsPT11 and OsPT13 knockout and knockdown mutants, Yang et al. (2012) have shown that not only OsPT11 but also OsPT13 is involved in AM symbiosis development. Although OsPT13 is essential for AM symbiosis, symbiotic phosphate uptake is independent of OsPT13. These results indicate functional specialization: OsPT11 may be responsible for both AM 


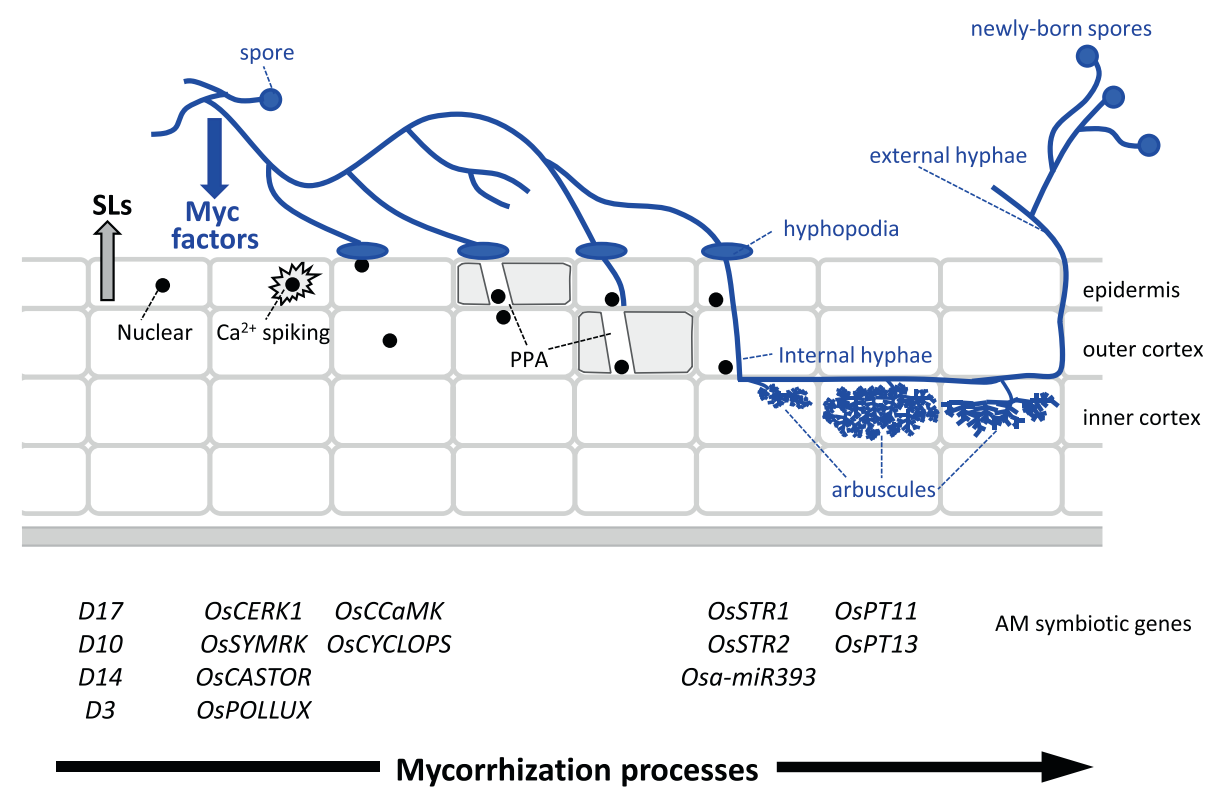

Fig. 1 Schematic view of mycorrhization and rice genes directly involved at each stage. SLs derived from host roots induce hyphal branching of AM fungi. At the same time, Myc factors secreted from AM fungi induce symbiotic $\mathrm{Ca}^{2+}$ spiking. At the tips of branched hyphae, hyphopodia are formed on the epidermis of host roots. Immediately beneath the hyphopodia, the pre-penetration apparatus (PPA) develops to guide hyphal penetration. In the inner cortex, arbuscules develop and act as a nutrient exchanger between the host plants and AM fungi

development and symbiotic phosphate uptake, whereas OsPT13 may act as a sensor to detect the phosphate level appropriate for arbuscule development (Yang et al., 2012).

\section{Rice as a model monocot plant to study the evolution of root nodule and AM symbioses}

Since the emergence of two legume models during 1990's, Lotus japonicus and Medicago truncatula, the door for analysis of molecular mechanisms of root symbioses has been opened. Legumes have two mutualistic symbiosis systems, root nodule (RN) and AM symbiosis.

Before the molecular genetics era in legume symbiosis, the presence of host plant genes governing both $\mathrm{RN}$ and AM symbioses has been suggested (Resenders et al. 2001). In line with this, over half of non-nodulation mutants of L. japonicus and M. truncatula also showed non-mycorrhization phenotypes (Kouchi et al. 2010, Oldroyd 2013). A set of genes shared by both symbioses was assumed to encode key components of the "common symbiosis pathway" (CSP) that regulates intracellular infection with rhizobial bacteria and AM fungi. Extensive studies since the 2000s have revealed that these CSP components function as activators of $\mathrm{Ca}^{2+}$ spiking (LjSYMRK/MtDMI2, LjCASTOR, LjPOLLUX/ MtDMI1, LjNUP85, LjNUP133, and LjNENA), a decoder of symbiotic $\mathrm{Ca}^{2+}$ signals ( $L j C C a M K / M t D M I 3$ ), and activators of downstream symbiotic signaling pathways (LjCYCLOPS/MtIPD3, MtVapyrin, LjNSP1, $M t N S P 2$, and LjCerberus, reviewed by Kouchi et al. 2010 and Oldroyd 2013).
AM symbiosis is formed between the majorities of plant species, while RN symbiosis is limited to a clade within Eurosid I. Thus, it has been proposed that RN symbiosis has originated from AM symbiosis by using basic CSP and a newly acquired set of genes for the RN specific pathway (Kistner and Parniske 2002). To examine this hypothesis, comparative analysis of orthologous genes between legumes and non-legumes became essential. Among the non-leguminous plants, rice is the most suitable monocot model plant, because its genome databases and mutant resources have already been established (Miyao et al. 2003, Hirochika et al. 2004). Zhu et al. (2006) reported the presence of putative rice orthologs of the legume genes NFR1, NFR5, SYMRK/ DMI2, CASTOR, POLLUX/DMI1, DMI3, MtNSP1, and $M t N S P 2$. Studies on knockout rice mutant lines showed that the OsCSP genes, OsCASTOR, OsPOLLUX, OsCCaMK, and OsCYCLOPS, are directly involved in AM symbiosis (see references in Table 1).

Heterologous complementation of legume symbiotic mutants with rice orthologs revealed that almost all rice genes examined rescued mycorrhization-defective phenotypes of corresponding mutants of $L$. japonicus or $M$. truncatula (Table 1). These results show functional conservation of these genes between rice and legumes in the regulation of AM symbiosis.

OSSYMRK, which encodes a symbiotic leucine-rich repeat (LRR) receptor kinase, failed to rescue bacterial endosymbiosis of the nodulation-defective Ljsymrk mutant (Markmann et al. 2008). In contrast to the other 
Table 1 List of rice genes whose involvement for AM and/or RN symbioses have been proven by rice mutant analysis and/or heterologous complementation analysis with legumes

\begin{tabular}{|c|c|c|c|c|c|c|c|}
\hline Gene & Gene ID & Protein annotation & Mycorrhization mutant lines & $\begin{array}{l}\text { Mycorrhization } \\
\text { phenotype }\end{array}$ & $\begin{array}{l}\text { RN rescue by } \\
\text { Os ortholog }\end{array}$ & $\begin{array}{l}\text { AM rescue by } \\
\text { Os ortholog }\end{array}$ & Ref. \\
\hline \multirow[t]{2}{*}{ OsCERK1 } & \multirow[t]{2}{*}{ Os08g0538300 } & \multirow[t]{2}{*}{ LysM receptor kinase } & Oscerk1-KO (null mutants ${ }^{* 2}$ ) & $\begin{array}{l}\text { Oscerk 1-KO: delayed } \\
\text { arbuscule formation }\end{array}$ & \multirow[t]{2}{*}{ Ljnfr1: Nod $^{+} \mathrm{Fix}^{+{ }^{*} 8}$} & \multirow[t]{2}{*}{$\mathrm{n} / \mathrm{a}^{* 9}$} & Miyata et al. (2014) \\
\hline & & & OsCERK1-RNAi & OsCERK1-RNAi:Myc- & & & Zhang et al. (2015) \\
\hline OsSYMRK & Os07g0568100 & LRR protein kinase & no hit $^{* 3}$ & - & Ljsymrk: Nod $^{+} \mathrm{Fix}^{-}$ & Ljsymrk: Myc ${ }^{+}$ & Markmann et al. (2008) \\
\hline \multirow[t]{3}{*}{ OSCASTOR } & \multirow[t]{3}{*}{ Os03g0843600 } & \multirow[t]{3}{*}{ Cation ion channel } & \multirow[t]{3}{*}{ Oscastor-1 (1B-08643 $\left.3^{* 4}\right)$} & \multirow[t]{3}{*}{$\mathrm{Myc}^{-}$} & \multirow[t]{3}{*}{ Ljcastor: $\mathrm{Nod}^{+} \mathrm{Fix}^{+}$} & \multirow[t]{3}{*}{ Ljcastor:Myc ${ }^{+}$} & Banba et al. (2008) \\
\hline & & & & & & & Gutjahr et al. (2008) \\
\hline & & & & & & & Chen et al. (2009) \\
\hline \multirow[t]{3}{*}{ OsPOLLUX } & \multirow[t]{3}{*}{ Os01g0870100 } & \multirow[t]{3}{*}{ Cation ion channel } & Ospollux-1 (1C-03411 $\left.1^{* 4}\right)$ & \multirow[t]{3}{*}{$\mathrm{Myc}^{-}$} & Ljpollux: Nod ${ }^{ \pm} \mathrm{Fix}^{-}$ & Ljpollux: Myc ${ }^{ \pm}$ & Banba et al. (2008) \\
\hline & & & Ospollux-2 (NC6423*5) & & Mtdmi1: $\mathrm{Nod}^{+} \mathrm{Fix}^{-}$ & Mtdmi1: $\mathrm{Myc}^{+}$ & Gutjahr et al. (2008) \\
\hline & & & Ospollux-3 (ND5050 $\left.{ }^{* 5}\right)$ & & & & Chen et al. (2009) \\
\hline \multirow[t]{4}{*}{ OsCCaMK/OsDMI3 } & \multirow[t]{4}{*}{ Os05g0489900 } & \multirow[t]{4}{*}{$\begin{array}{l}\mathrm{Ca}^{2+} / \mathrm{CaM} \text {-dependent } \\
\text { protein kinase }\end{array}$} & Osccamk-1 (NE1115\%5) & \multirow[t]{4}{*}{$\mathrm{Myc}^{-}$} & $\begin{array}{l}\text { Ljccamk: } \\
\text { Nod }^{+} \mathrm{Fix}^{+} / \mathrm{Spn}^{+}\end{array}$ & Ljccamk: Myc ${ }^{+}$ & Godfroy et al. (2006) \\
\hline & & & \multirow{3}{*}{$\begin{array}{l}\left.\text { Osccamk-2 (NF8513 } 3^{* 5}\right) \\
\text { OsDMI3-i (RNAi) }\end{array}$} & & \multirow[t]{3}{*}{ Mtdmi3: $\mathrm{Nod}^{+} \mathrm{Fix}^{-}$} & \multirow[t]{3}{*}{ Mtdmiz: $\mathrm{Myc}^{+}$} & Chen et al. (2007) \\
\hline & & & & & & & Banba et al. (2008) \\
\hline & & & & & & & Gutjahr et al. (2008) \\
\hline \multirow[t]{6}{*}{ OsCYCLOPS/OsIPD3 } & \multirow[t]{6}{*}{ Os06g0115600 } & \multirow{6}{*}{$\begin{array}{l}\text { interacting protein of } \\
\text { CCaMK }\end{array}$} & 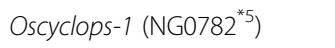 & \multirow[t]{6}{*}{$\mathrm{Myc}^{-}$} & \multirow[t]{6}{*}{ Ljcyclops: $\mathrm{Nod}^{+} \mathrm{Fix}^{+}$} & \multirow[t]{6}{*}{ Ljcyclops:Myc ${ }^{+}$} & Yano et al. (2008) \\
\hline & & & Oscyclops-2 $\left(\mathrm{NC2415^{*5 } )}\right.$ & & & & Gutjahr et al. (2008) \\
\hline & & & Oscyclops-3 $\left(\mathrm{NC2713^{*5 }}\right)$ & & & & Chen et al. (2008) \\
\hline & & & ND5032 $2^{*}$ & & & & \\
\hline & & & $\mathrm{NCO} 263^{* 5}$ & & & & \\
\hline & & & $N C 2794^{* 5}$ & & & & \\
\hline OsNSP1 & Os03g0408600 & GRAS TF & no hit $^{* 3}$ & - & Ljnsp 1: $\mathrm{Nod}^{+} \mathrm{Fix}^{+}$ & - & Yokota et al. (2010) \\
\hline OSNSP2 & Os03g0263300 & GRAS TF & no hit $^{* 3}$ & - & Ljnsp2: $\mathrm{Nod}^{+} \mathrm{Fix}^{+}$ & $\mathrm{n} / \mathrm{a}^{* 9}$ & Yokota et al. (2010) \\
\hline \multirow[t]{2}{*}{ OsPT11 } & \multirow[t]{2}{*}{ Os01g0657100 } & Phosphate transporter & Ospt11-1 ${ }^{* 4}$ & Low mycorrhizaion & - & - & Yang et al. (2012) \\
\hline & & & Ospt11R1 (RNAi) & & & & \\
\hline OsPT13 & Os04g0186800 & Phosphate transporter & Ospt13-1 $1^{* 7}$ & Low mycorrhizaion & - & - & Yang et al. (2012) \\
\hline & & & Ospt13R1 (RNAi) & (small arbuscules) & & & \\
\hline OsSTR1 & Os09g0401100 & half-size $A B C$ transporter & $\operatorname{str1-1}\left(1 \mathrm{C}-04850^{* 4}\right)$ & Small and stunted & - & - & Gutjahr et al. (2012) \\
\hline & & & str1-2 (CL522472 $\left.{ }^{* 6}\right)$ & arbuscules in cortex & & & \\
\hline OsSTR2 & Os07g0191600 & half-size $A B C$ transporter & str-2-1 (RdSpm2654D*7) & $\begin{array}{l}\text { Small and stunted } \\
\text { arbuscules in cortex }\end{array}$ & - & - & Gutjahr et al. (2012) \\
\hline
\end{tabular}


Table 1 List of rice genes whose involvement for AM and/or RN symbioses have been proven by rice mutant analysis and/or heterologous complementation analysis with legumes (Continued)

\begin{tabular}{|c|c|c|c|c|c|c|c|}
\hline \multirow[t]{3}{*}{$\overline{\mathrm{D} 17}$} & \multirow[t]{3}{*}{ Os04g0550600 } & \multirow[t]{3}{*}{ CCD7/SL biosynthesis } & \multirow[t]{3}{*}{$d 17-1$} & \multirow[t]{3}{*}{ Low mycorrhization } & \multirow[t]{3}{*}{-} & \multirow[t]{3}{*}{-} & Umehara et al. (2008) $)^{* 10}$ \\
\hline & & & & & & & Gutjahr et al. (2012) \\
\hline & & & & & & & Yoshida et al. (2012) \\
\hline \multirow[t]{2}{*}{ D10 } & \multirow[t]{2}{*}{ Os01g0746400 } & \multirow[t]{2}{*}{ CCD8/SL biosynthesis } & d10-1 & \multirow[t]{2}{*}{ Low mycorrhization } & \multirow[t]{2}{*}{-} & \multirow[t]{2}{*}{-} & Umehara et al. (2008) ${ }^{*} 10$ \\
\hline & & & d10-2 & & & & Gutjahr et al. (2012) \\
\hline \multirow[t]{2}{*}{ D14 } & \multirow[t]{2}{*}{ Os03g0203200 } & \multirow{2}{*}{$\begin{array}{l}\text { a/ } / \text {-fold hydorolase/SL } \\
\text { signaling }\end{array}$} & d14-1 & \multirow[t]{2}{*}{ High mycorrhization } & \multirow[t]{2}{*}{-} & \multirow[t]{2}{*}{-} & Ishikawa et al. $(2005)^{* 10}$ \\
\hline & & & & & & & Yoshida et al. (2012) \\
\hline \multirow[t]{3}{*}{ D3 } & \multirow[t]{3}{*}{ Os06g0154200 } & \multirow{3}{*}{$\begin{array}{l}\text { F-box Leu-rich repeat } \\
\text { protein/SL signaling }\end{array}$} & $d 3-1$ & \multirow[t]{3}{*}{ Myc $^{-}$} & \multirow[t]{3}{*}{-} & \multirow[t]{3}{*}{-} & \multirow[t]{3}{*}{ Yoshida et al. (2012) ${ }^{* 10}$} \\
\hline & & & $d 3-2$ & & & & \\
\hline & & & $d 3-3$ & & & & \\
\hline osa-miR393a & MIMAT0000957 $7^{* 1}$ & $\begin{array}{l}\text { microRNA down-regulates } \\
\text { auxin receptor genes }\end{array}$ & ox-Os-miR393 & Low mycorrhization & - & - & Etemadi et al. (2014) \\
\hline
\end{tabular}

${ }^{*} 1$ : miRBase: the microRNA database (http://www.mirbase.org/index.shtml)

${ }^{*} 2$ : gene targeting lines lacking initiation codon

*3: no hit in Tos17 open line

*4: mutant lines derived from POSTECH (http://cbi.khu.ac.kr/RISD_DB.html)

*5: mutant lines derived from NIAS Tos17 rice mutant panel (https://tos.nias.affrc.go.jp/)

*6: mutant lines derived from FST-Genoplante (http://oryzatagline.cirad.fr/)

*7: Rice Transposon Flanking Sequence Tag Database (http://sundarlab.ucdavis.edu/rice/blast/blast.html)

*8: tested by a chimeric gene consisting of a ectodomain of LjNFR1 and a intracellular domain of OsCERK1

*9: these mutants show normal mycorrhization phenotype in L. japonicus

*10: articles in which information of mutant lines are described.

$\mathrm{Nod}^{-}$: non-nodulation

Nod $^{+} \mathrm{Fix}^{-}$: nodulation + bacterial entry-

Nod $^{ \pm}$Fix $^{-}$: occasional rescue of nodulation + bacterial entry-

$\mathrm{Nod}^{+} \mathrm{Fix}^{+}$: nodulation + nitrogen fixation+

$\mathrm{Spn}^{+}:$spontaneous nodulation+
$\mathrm{Myc}^{-}$: no cortex invasion and no arbuscule formation

Myc $c^{ \pm}$: occasional rescue of mycorrhization

$\mathrm{Myc}^{+}$: mycorrhization+ 
OsCSP genes, which have similar domain structures as those of legumes (Banba et al., 2008, Gutjahr et al., 2008, Yano et al., 2008), a comparison of structure among SYMRK orthologs showed the presence of additional domains at the N-terminus of LjSYMRK. Thus, 'full-version' LjSYMRK regulates both RN and AM symbioses, whereas 'short-version' OsSYMRK regulates AM symbiosis only, suggesting that stepwise domain acquisition by SYMRK has contributed to the evolution of RN symbiosis (Markmann et al. 2008).

In L. japonicus, CASTOR and POLLUX are twin cation channels that function non-redundantly (ImaizumiAnraku et al. 2005, Venkateshwaran et al. 2012). Neither rhizobial nor mycorrhizal symbioses are complemented in the roots of Ljpollux mutant expressing OsPOLLUX (OsPOLLUX/Ljpollux), while both rhizobial and mycorrhizal symbioses occur in the roots of OsCASTOR/Ljcastor (Banba et al. 2008). In this view, incomplete rescue of Ljpollux by OsPOLLUX may be caused by incompatibility between LjCASTOR and OsPOLLUX in Ljpollux mutant, conversely, heterologous combination of OsCASTOR and LjPOLLUX may be sufficient to rescue Ljcastor mutant. In M. truncatula, DMI1, the ortholog of POLLUX, acts in the absence of CASTOR, because a serine-to-alanine substitution in its filter region, a highly conserved ADS/AGNHA amino acid residues in the $4^{\text {th }}$ transemembrane domain, confers the integrated function of CASTOR and POLLUX (Venkateshwaran et al., 2012). In the Mtdmi1 mutant, OsPOLLUX cannot rescue rhizobial endosymbiosis, probably because OsPOLLUX retains the Ser residue in the filter region (Imaizumi-Anraku et al. 2005, Chen et al. 2009).

OsCCaMK and OsCYCLOPS rescue nodulationdefective phenotypes of the corresponding mutants of M. truncatula and/or L. japonicus (Godfroy et al. 2006, Chen et al. 2007, Banba et al. 2008, Yano et al. 2008, Chen et al. 2008). CCaMK/DMI3 encodes a $\mathrm{Ca}^{2+}$, CaMdependent protein kinase, which consists of kinase, CaM-binding (CaMBD), and EF-hand domains. CCaMK is a key player in RN and AM symbioses and acts as a decoder of symbiotic $\mathrm{Ca}^{2+}$ signals. Functional analysis of CCaMK revealed the dispensability of its CaMBD and EF-hand domains for AM symbiosis, because the mutants with deleted CaMBD and EF hand domains are able to accommodate AM fungi (Shimoda et al., 2012, Takeda et al. 2012). On the other hand, full-length CCaMK is indispensable for the infection of rhizobial bacteria (Shimoda et al. 2012). These results raise the possibilities that CCaMK plays a role in sorting the signals derived from $\mathrm{AM}$ or $\mathrm{RN}$ symbioses and that $\mathrm{RN}$ symbiosis requires more complex regulation of CCaMK through CaMBD/EF hand domains (Takeda et al. 2012). The domain structure of CCaMK orthologs from nonleguminous mycorrhizal plants is similar to that of legumes (Yang et al. 2011). In abscisic acid signaling, OsCCaMK induces antioxidant defense (Shi et al. 2012, 2014), which implies its yet unidentified roles in nonleguminous plants. CYCLOPS, a phosphorylation target of CCaMK, plays a role in transactivation of the NIN gene in the RN-specific pathway (Singh et al. 2014), whereas the downstream target of CYCLOPS in AM symbiosis remains unknown.

These complementation studies discussed above suggest that the CSP genes, except SYMRK, have remained unchanged during the evolution of $\mathrm{RN}$ symbiosis and constituted the molecular basis for the symbiotic signaling.

\section{Is CSP also involved in responses to infecting microorganisms in rice?}

There is a myriad of microorganisms in the rhizosphere. Do they interact with plant roots via CSP? The rice blast fungus Magnaporthe oryzae infects the roots of Oscastor-1 and Osccamk-2 mutants similarly to those of wild type, indicating that the OsCSP genes are not required for this infection (Marcel et al. 2010). Endophytic colonization of the rice mutants Oscastor-1, Osccamk-2, and Oscyclops (NC2794) by rhizobia also appears not to be affected under laboratory conditions (Chen and Zhu 2013). However, the OsCCaMK genotype affects the diversity of the bacterial community in rice roots in paddy and upland fields (Ikeda et al. 2011). Minamisawa and colleagues showed that the abundance of Alphaproteobacteria (Sphingomonadales and Rhizobiales), which are ubiquitous in the environment, was drastically decreased on the Osccamk-1 roots in comparison with wild-type roots (Ikeda et al. 2011). In the paddy fields under low nitrogen conditions, the methanotrophic community (mainly Methylomonas and Methylomicrobium in type I methanotrophs) was less diverse in the Osccamk-1 roots than in the wild-type roots; the enhanced $\mathrm{CH}_{4}$ flux of the Osccamk-1 mutant suggests a positive influence of OsCCaMK on $\mathrm{CH}_{4}$ oxidation (Bao et al. 2014).

\section{Choice between symbiosis and defense response: two faces of OsCERK1}

In RN symbiosis, CSP is activated upon recognition of rhizobial symbiotic signal molecules, Nod factors, by host lysine motif (LysM) receptor-like kinases, NFR1/ LYK3 and NFR5/NFP. The Nod factors are diversely modified derivatives of lipochitooligosaccharides (LCOs) and are also called Nod-LCOs. Similarly to rhizobia, AM fungi secrete diffusible signal molecules (Kosuta et al. 2003). One type of the mycorrhizal (Myc) factors, MycLCOs, are structurally similar to Nod-LCOs, but have a simpler structure (Maillet et al. 2011), implying that the receptors for AM fungal signals are also similar to those for Nod-LCO receptors. This suggestion is supported by 
the fact that a single copy of an NFR5/NFP homolog participates in both RN and AM symbioses in Parasponia, the only known non-legume plant that establishes rhizobial symbiosis (Op den Camp et al. 2011).

Myc-LCOs improve mycorrhization (Maillet et al. 2011). In M. truncatula, they induce the expression of a number of genes, which partially overlap with but are largely distinct from the genes induced by Nod-LCOs (Czaja et al. 2012). Curiously, most of these responses in M. truncatula require NFP (Maillet et al. 2011, Czaja et al. 2012), although the mycorrhization phenotype of Mtnfp appears not to be affected. These perplexing results might indicate the different dependence of AM symbiosis on the Myc-LCO/NFP system among plant species. It is noteworthy that NFR5/NFP homologs are found in a wide range of mycorrhizal plants (Zhu et al. 2006, Zhang et al. 2007), suggesting their importance.

Homologs of NFR1/LYK3 are also conserved among plants (Zhu et al. 2006, Zhang et al. 2007, De Mita et al. 2014). OsCERK1, the closest rice homolog of NFR1/ LYK3, recognizes chitin or peptidoglycan and triggers plant immunity responses (Miya et al. 2007, Shimizu et al. 2010, Willmann et al. 2011). Although their physiological roles-acceptance or rejection of infecting microbes-are seemingly opposite, these genes may be descendants of a common ancestral gene (Nakagawa et al. 2011, Oldroyd 2013, Miyata et al. 2014). This view is supported by transient induction of a number of defense genes by Nod-LCOs in an NFR1-dependent manner in L. japonicus (Nakagawa et al. 2011) and by the findings that co-expression of either LjNFR1 with LjNFR5 or MtLYK3 with MtNFP causes cell death in Nicotiana benthamiana (Madsen et al. 2011, Pietraszewska-Bogiel et al. 2013). Therefore, NFR1/LYK3 also bears some traits related to defense responses, a feature reminiscent of CERK1.

The ectodomains of NFR1 and CERK1 distinguish between Nod-LCOs and chitin oligomers (Broghammer et al. 2012, Wang et al. 2014), and their intracellular kinase domains play crucial roles in triggering nodulation or immunity responses, respectively (Petutschnig et al. 2010, Madsen et al. 2011). Despite the contrasting functions of the two kinases, chimeric constructs consisting of the ectodomain of LjNFR1 and the kinase domain of OsCERK1 rescue the nodulation defect of the Ljnfr1 mutant (Nakagawa et al. 2011, Miyata et al. 2014), suggesting the ability of OsCERK1 to regulate symbiotic interactions. Indeed, the Oscerk1 null mutants (Kouzai et al. 2014a) are impaired in both chitin-triggered immunity and AM symbiosis (Miyata et al. 2014). Yet, these two functions are not necessarily coupled because the Oscebip mutant (Kouzai et al. 2014b) has defective chitintriggered immunity but normal AM symbiosis (Miyata et al. 2014). In the oscerk 1 null mutants, AM fungal infection is initially blocked at the root surface but prolonged cultivation eventually allows penetration of fungal hyphae into the root cortex and arbuscular formation (Miyata et al. 2014). In contrast, OsCERK1knockdown lines clearly show an impaired mycorrhization phenotype (Zhang et al. 2015) even at the time point corresponding to "prolonged cultivation" in oscerk1 null mutants in the study by Miyata et al. (2014). Although the mycorrhizal conditions differed in the two studies, different phenotypes of the oscerk1 null mutants and OsCERK1-knockdown lines might imply the existence of a functionally redundant gene. The bifunctionality of OsCERK1 raises a question of how the same receptor selectively triggers the opposite physiological responses. In response to microorganisms, OsCERK1 appears to recruit appropriate receptor partners to form symbiotic or defensive receptor complexes by which the initial interactions are determined.

\section{Reverse genetic approaches of rice provide new insights into AM symbiosis}

Reverse genetic approaches have identified novel AM symbiosis genes in rice. Genome-wide microarray analysis of mycorrhized rice roots revealed 224 genes the expression of which was altered in response to mycorrhization (Güimil et al. 2005). These OsAM genes were used for molecular phenotyping of the Oscsp mutants, which resulted in identification of an alternative signaling pathway independent of CSP (Gutjahr et al. 2008). Furthermore, 76 of OsAM genes showed similar expression patterns of mono- and dicotyledonous plants, shedding light on a conserved molecular mechanism governing AM symbiosis (Güimil et al. 2005).

The expression of two half-size $\mathrm{ABC}$ transporters, STR1 and STR2, is enhanced during AM symbiosis, and these transporters are directly involved in arbuscule development (Gutjahr et al. 2012).

Two markers, OsPT11-GFP, localized in the periarbuscular membrane (Kobae and Hata 2010) and GFPAM42, localized in the arbuscule, enable observation of arbuscule development (Kobae and Fujiwara 2014). Long-term live imaging of transgenic OsPT11-GFP and GFP-AM42 rice roots revealed a short life-span of arbuscules and repetitive de novo colonization of rice roots by AM fungi.

Plant hormones, e.g., abscisic acid, gibberellin, auxin, and SLs, are involved in AM symbiosis (Foo et al. 2013). In rice, the overexpression of osmiR393, a microRNA that targets several auxin receptors, results in downregulation of auxin receptor genes and hampers arbuscule development (Etemadi et al. 2014). 


\section{Relationship between strigolactone biosynthesis and mycorrhization}

Identification of SLs as branching factors (Akiyama et al. 2005) has led to a breakthrough in understanding of the molecular mechanisms of the pre-contact stage of AM symbiosis. SLs also act as plant hormones to regulate shoot branching (Domagalska and Leyser 2011). In rice, the causative genes of the increased-tiller-outgrowth mutants, $d 17, d 10, d 27, d 14$ and $d 3$ have been identified as SL-biosynthesis (D17, D10 and D27) or SL-signaling (D14 and D3) genes. In $d 10$ and $d 17$ mutants, the rates of colonization by AM fungi are decreased, whereas arbuscule structures are not affected (Gutjahr et al. 2012), indicating that SLs are dispensable for arbuscule development. Because SLs are undetectable in root exudates of these mutants (Umehara et al. 2008), their mycorrhization phenotypes are likely to be associated with incomplete induction of hyphal branching, which may determine the lower frequency of AM fungal infection.

The crosstalk between the SL synthesis pathway and the GRAS transcription factors NSP1 and NSP2 has been shown in rice. A decreased expression of $D 27$ was detected in the Osnsp1/Osnsp2 double knockdown lines (Liu et al. 2011) and in the nsp1, nsp2, and nsp1/ nsp2 background of M. truncatula and L. japonicus (Liu et al. 2011, Takeda et al. 2013, Nagae et al. 2014). However, the colonization rate of the Ljnsp1 mutant was not restored by application of SL analog, GR24, suggesting that the attenuation of the SL biosynthesis pathway is not a major determinant of the mycorrhization defect of this mutant (Takeda et al. 2013).

The $d 3$ and $d 14$ mutants are SL-insensitive and synthesize more SLs and induce highly branched hyphae around their roots in comparison with wild type (Umehara et al. 2008, Yoshida et al. 2012). As expected, d14 shows a high-mycorrhization phenotype. However, the development of hyphopodia on $d 3$ roots is arrested (Yoshida et al. 2012) and the mode of action of D3 at the initial penetration stage of AM fungi remains elusive.

\section{Conclusions and Perspective}

As reviewed here, rice has made a major contribution to the elucidation of molecular mechamisms of AM symbiosis, as a model monocot plant. On the other hand, rice is one of three major cereals and has a direct impact on food supplies. Conventional agriculture largely depends on the input of phosphorus fertilizer; the output of mineral phosphorus is expected to reach a peak around 2030, and then to take a downward turn (Cordell et al. 2009). Under these circumstances, rice cultivars that need less phosphorus are an important breeding target (Kochian 2012). As a successful example of such approach, the protein kinase Pstol1, initially detected in cultivar Kasalath as a QTL for phosphorus-deficiency tolerance (Pup1), was used to confer tolerance to phosphorus deficiency in phosphorus-starvation-intolerant modern cultivars. Pstol1 acts as an enhancer of root growth, thereby allowing host plants to absorb more phosphorus (Gamuyao et al. 2012).

In general, rice is grown in flooded fields, where mycorrhization is inhibited under anaerobic conditions, in part because of reduced spore abundance of AM fungi in comparison with dry conditions (Ilag et al. 1987). Regardless of rice varieties, colonization by AM fungi is substantially reduced under flooded conditions (Vallino et al. 2009). AM symbiosis can be used for rice cultivation under flooded conditions (Secilia and Bagyaraj 1992, 1994, Solaiman and Hirata 1997, 1998); however, rice breeding to use AM symbiosis for phosphate uptake remains out of reach.

Even though modern rice cultivars are grown under anaerobic conditions, the amount of inorganic phosphate (Pi) uptake through AM symbiosis accounts for $70 \%$ of total $\mathrm{Pi}$ absorbed by rice cultivar Nipponbare under experimental condition. In addition, cultivar IR66 maintains elevated expression levels of AM marker genes under both aerobic and anaerobic field conditions, suggesting high dependency of rice $\mathrm{Pi}$ uptake on the mycorrhizal pathway (Yang et al. 2012). Although rice flooding has a negative impact on AM fungal colonization, AM fungi that had entered into rice roots before flooding remain viable in the roots under anaerobic conditions. Furthermore, basic functionality of AM symbiosis is not affected by flooding (Maiti et al. 2008 and Vallino et al. 2014). Therefore, rice seems to be a potential target for breeding to increase productivity through AM symbiosis.

\section{Competing interests}

The authors declare that they have no competing interests.

\section{Authors' contribution}

TN and HI-A wrote the first draft. HI-A completed the manuscript writing. Both authors read and approved the final manuscript.

\section{Acknowledgements}

We thank Drs Carolina Gutjahr (University of Munich), Naoya Takeda (National Institute for Basic Biology), Keisuke Yokota (RIKEN), Jyunko Kyozuka (University of Tokyo) and Hiromu Kameoka (University of Tokyo) for providing useful information about rice AM symbiosis.

\section{Author details}

'Division of Symbiotic Systems, National Institute for Basic Biology, Nishigonaka 38Myodaiji, Okazaki, Aichi 444-8585, Japan. ${ }^{2}$ Division of Biological Science, Graduate School of Science, Nagoya University, Nagoya, Aichi 464-8602, Japan. ${ }^{3}$ Division of Plant Sicences, National Institute of Agrobiological Sciences, 2-1-2 Kannon-dai, Tsukuba, Ibaraki 305-8602, Japan.

Received: 25 February 2015 Accepted: 22 October 2015 Published online: 30 October 2015

\section{References}

Akiyama K, Matsuzaki K, Hayashi H (2005) Plant sesquiterpenes induce hyphal branching in arbuscular mycorrhizal fungi. Nature 435:824-827

Banba M, Gutjahr C, Miyao A, Hirochika H, Paszkowski U, Kouchi H, ImaizumiAnraku H (2008) Divergence of evolutionary ways among common sym 
genes: CASTOR and CCAMK show functional conservation between two symbiosis systems and constitute the root of a common signaling pathway. Plant Cell Physiol 49:1659-1671

Bao Z, Watanabe A, Sasaki K, Okubo T, Tokida T, Liu D, Ikeda S, Imaizumi-Anraku H, Asakawa S, Sato T, Mitsui H, Minamisawa K (2014) A rice gene for microbial symbiosis, Oryza sativa CCaMK, reduces $\mathrm{CH} 4$ flux in a paddy field with low nitrogen input. Appl Environ Microbiol 80:1995-2003

Broghammer A, Krusell L, Blaise M, Sauer J, Sullivan JT, Maolanon N, Vinther M, Lorentzen A, Madsen EB, Jensen KJ, Roepstorff P, Thirup S, Ronson CW, Thygesen MB, Stougaard J (2012) Legume receptors perceive the rhizobial lipochitin oligosaccharide signal molecules by direct binding. Proc Natl Acad Sci U S A 109:13859-13864

Chen C, Ané J-M, Zhu H (2008) OsIPD3, an ortholog of the Medicago truncatula DMI3 interacting protein IPD3, is required for mycorrhizal symbiosis in rice. New Phytol 180:311-315

Chen C, Fan C, Gao M, Zhu H (2009) Antiquity and function of CASTOR and POLLUX, the twin ion channel-encoding genes key to the evolution of root symbioses in plants. Plant Physiol 149:306-317

Chen C, Gao M, Liu J, Zhu H (2007) Fungal symbiosis in rice requires an ortholog of a legume common symbiosis gene encoding a Ca2+/calmodulindependent protein kinase. Plant Physiol 145:1619-1628

Chen C, Zhu H (2013) Are common symbiosis genes required for endophytic rice-rhizobial interactions? Plant Signal Behav 8, e25453

Cordell D, Drangert J-O, White S (2009) The story of phosphorus: Global food security and food for thought. Glob Environ Chang 19:292-305

Czaja LF, Hogekamp C, Lamm P, Maillet F, Martinez EA, Samain E, Denarie J, Kuster H, Hohnjec N (2012) Transcriptional responses toward diffusible signals from symbiotic microbes reveal MtNFP- and MtDMl3-dependent reprogramming of host gene expression by arbuscular mycorrhizal fungal lipochitooligosaccharides. Plant Physiol 159:1671-1685

De Mita S, Streng A, Bisseling T, Geurts R (2014) Evolution of a symbiotic receptor through gene duplications in the legume-rhizobium mutualism. New Phyto 201:961-972

Domagalska MA, Leyser O (2011) Signal integration in the control of shoot branching. Nat Rev Mol Cell Biol 12:211-221

Etemadi M, Gutjahr C, Couzigou JM, Zouine M, Lauressergues D, Timmers A Audran C, Bouzayen M, Bécard G, Combier JP (2014) Auxin perception is required for arbuscule development in arbuscular mycorrhizal symbiosis. Plant Physiol 166:281-292

Foo E, Ross JJ, Jones WT, Reid JB (2013) Plant hormones in arbuscular mycorrhizal symbioses: an emerging role for gibberellins. Ann Bot 111:769-779

Gamuyao R, Chin JH, Pariasca-Tanaka J, Pesaresi P, Catausan S, Dalid C, SlametLoedin I, Tecson-Mendoza EM, Wissuwa M, Heuer S (2012) The protein kinase Pstol1 from traditional rice confers tolerance of phosphorus deficiency. Nature 488:535-539

Genre A, Chabaud M, Timmers T, Bonfante P, Barker DG (2005) Arbuscular Mycorrhizal Fungi Elicit a Novel Intracellular Apparatus in Medicago truncatula Root Epidermal Cells before Infection. Plant Cell 17:3489-3499

Godfroy O, Debellé F, Timmers T, Rosenberg C (2006) A rice calcium- and calmodulin-dependent protein kinase restores nodulation to a legume mutant. Mol Plant Microbe Interact 19:495-501

Güimil S, Chang HS, Zhu T, Sesma A, Osbourn A, Roux C, loannidis V, Oakeley EJ Docquier M, Descombes P, Briggs SP, Paszkowski U (2005) Comparative transcriptomics of rice reveals an ancient pattern of response to microbial colonization. Proc Natl Acad Sci U S A 102:8066-8070

Gutjahr C, Banba M, Croset V, An K, Miyao A, An G, Hirochika H, Imaizumi-Anraku H, Paszkowski U (2008) Arbuscular mycorrhiza-specific signaling in rice transcends the common symbiosis signaling pathway. Plant Cell 20:2989-3005

Gutjahr C, Radovanovic D, Geoffroy J, Zhang Q, Siegler H, Chiapello M, Casieri L, An K, An G, Guiderdoni E, Kumar CS, Sundaresan V, Harrison MJ, Paszkowski U (2012) The half-size ABC transporters STR1 and STR2 are indispensable for mycorrhizal arbuscule formation in rice. Plant J 69:906-920

Hirochika H, Guiderdoni E, An G, Hsing YI, Eun MY, Han CD, Upadhyaya N, Ramachandran S, Zhang Q, Pereira A, Sundaresan V, Leung H (2004) Rice mutant resources for gene discovery. Plant Mol Biol 54:325-334

Ikeda S, Okubo T, Takeda N, Banba M, Sasaki K, Imaizumi-Anraku H, Fujihara S, Ohwaki Y, Ohshima K, Fukuta Y, Eda S, Mitsui H, Hattori M, Sato T, Shinano T, Minamisawa K (2011) The genotype of the calcium/calmodulin-dependent protein kinase gene (CCaMK) determines bacterial community diversity in rice roots under paddy and upland field conditions. Appl Environ Microbio 77:4399-4405
Ilag LL, Rosales AM, Elazegui FA, Mew TW (1987) Changes in the population of infective endomycorrhizal fungi in a rice-based cropping system. Plant and Soil 103:67-73

Imaizumi-Anraku H, Takeda N, Charpentier M, Perry J, Miwa H, Umehara Y, Kouchi H, Murakami Y, Mulder L, Vickers K, Pike J, Downie JA, Wang T, Sato S, Asamizu E, Tabata S, Yoshikawa M, Murooka Y, Wu G-J, Kawaguchi M, Kawasaki S, Parniske M, Hayashi M (2005) Plastid proteins crucial for symbiotic fungal and bacterial entry into plant roots. Nature 433:527-531

Ishikawa S, Maekawa M, Arite T, Onishi K, Takamure I, Kyozuka J (2005) Suppression of tiller bud activity in tillering dwarf mutants of rice. Plant Cell Physiol 46:79-86

Kistner C, Parniske M (2002) Evolution of signal transduction in intracellular symbiosis. Trends Plant Sci 7:511-518

Kobae Y, Fujiwara T (2014) Earliest colonization events of Rhizophagus irregularis in rice roots occur preferentially in previously uncolonized cells. Plant Cell Physiol 55:1497-1510

Kobae Y, Hata S (2010) Dynamics of periarbuscular membranes visualized with a fluorescent phosphate transporter in arbuscular mycorrhizal roots of rice. Plant Cell Physiol 51:341-353

Kouchi H, Imaizumi-Anraku H, Hayashi M, Hakoyama T, Nakagawa T, Umehara Y, Suganuma N, Kawaguchi M (2010) How many peas in a pod? Legume genes responsible for mutualistic symbioses underground. Plant Cell Physiol 51:1381-1397

Kochian LV (2012) Rooting for more phosphorus. Nature 488:466-467

Kosuta S, Chabaud M, Lougnon G, Gough C, Denarie J, Barker DG, Becard G (2003) A diffusible factor from arbuscular mycorrhizal fungi induces symbiosis-specific MtENOD11 expression in roots of Medicago truncatula. Plant Physiol 131:952-962

Kouzai Y, Mochizuki S, Nakajima K, Desaki Y, Hayafune M, Miyazaki H, Yokotani N, Ozawa K, Minami E, Kaku H, Shibuya N, Nishizawa Y (2014a) Targeted gene disruption of OsCERK1 reveals its indispensable role in chitin perception and involvement in the peptidoglycan response and immunity in rice. Mol Plant Microbe Interact 27:975-982

Kouzai Y, Nakajima K, Hayafune M, Ozawa K, Kaku H, Shibuya N, Minami E, Nishizawa $Y(2014 b)$ CEBiP is the major chitin oligomer-binding protein in rice and plays a main role in the perception of chitin oligomers. Plant $\mathrm{Mol}$ Biol 84(4-5):519-528

Liu W, Kohlen W, Lillo A, Op den Camp R, Ivanov S, Hartog M, Limpens E, Jamil M, Smaczniak C, Kaufmann K, Yang WC, Hooiveld GJ, Charnikhova T, Bouwmeester HJ, Bisseling T, Geurts R (2011) Strigolactone biosynthesis in Medicago truncatula and rice requires the symbiotic GRAS-type transcription factors NSP1 and NSP2. Plant Cell 23:3853-3865

Madsen EB, Antolin-Llovera M, Grossmann C, Ye J, Vieweg S, Broghammer A, Krusell L, Radutoiu S, Jensen ON, Stougaard J, Parniske M (2011) Autophosphorylation is essential for the in vivo function of the Lotus japonicus Nod factor receptor 1 and receptor-mediated signalling in cooperation with Nod factor receptor 5. Plant J 65:404-417

Maillet F, Poinsot V, Andre O, Puech-Pages V, Haouy A, Gueunier M, Cromer L, Giraudet D, Formey D, Niebel A, Martinez EA, Driquez H, Becard G, Denarie J (2011) Fungal lipochitooligosaccharide symbiotic signals in arbuscular mycorrhiza. Nature 469:58-63

Maiti D, Barnwal MK, Singh RK (2008) Exploring possibility of utilizing native arbuscular mycorrhizal fungi for improving phosphorus nutrition in transplanted rice (Oryza sativa L.) of plateau region. Indian Phytopath 61:302-304

Marcel S, Sawers R, Oakeley E, Angliker H, Paszkowski U (2010) Tissue-adapted invasion strategies of the rice blast fungus Magnaporthe oryzae. Plant Cel 22:3177-3187

Markmann K, Giczey G, Parniske M (2008) Functional adaptation of a plant receptor- kinase paved the way for the evolution of intracellular root symbioses with bacteria. PLoS Biol 6, e68

Miya A, Albert P, Shinya T, Desaki Y, Ichimura K, Shirasu K, Narusaka Y, Kawakami N, Kaku H, Shibuya N (2007) CERK1, a LysM receptor kinase, is essential for chitin elicitor signaling in Arabidopsis. Proc Natl Acad Sci U S A 104:19613-19618

Miyao A, Tanaka K, Murata K, Sawaki H, Takeda S, Abe K, Shinozuka Y, Onosato K, Hirochika H (2003) Target site specificity of the Tos 17 retrotransposon shows a preference for insertion within genes and against insertion in retrotransposon-rich regions of the genome. Plant Cell 15:1771-1780

Miyata K, Kozaki T, Kouzai Y, Ozawa K, Ishii K, Asamizu E, Okabe Y, Umehara Y, Miyamoto A, Kobae Y, Akiyama K, Kaku H, Nishizawa Y, Shibuya N, Nakagawa 
T (2014) The bifunctional plant receptor, OsCERK1, regulates both chitintriggered immunity and arbuscular mycorrhizal symbiosis in rice. Plant Cell Physiol 55:1864-1872

Nagae M, Takeda N, Kawaguchi M (2014) Common symbiosis genes CERBERUS and NSP1 provide additional insight into the establishment of arbuscular mycorrhizal and root nodule symbioses in Lotus japonicus. Plant Signal Behav 9:e28544

Nakagawa T, Kaku H, Shimoda Y, Sugiyama A, Shimamura M, Takanashi K, Yazak K, Aoki T, Shibuya N, Kouchi H (2011) From defense to symbiosis: limited alterations in the kinase domain of LysM receptor-like kinases are crucial for evolution of legume-Rhizobium symbiosis. Plant J 65:169-180

Oldroyd GE (2013) Speak, friend, and enter: signaling systems htah promote beneficial symbiotic associations in plants. Nat Rev Microbiol 11:252-263

Op den Camp R, Streng A, De Mita S, Cao Q, Polone E, Liu W, Ammiraju JS, Kudrna D, Wing R, Untergasser A, Bisseling T, Geurts R (2011) LysM-type mycorrhizal receptor recruited for rhizobium symbiosis in nonlegume Parasponia. Science 331:909-912

Paszkowski U, Kroken S, Roux C, Briggs SP (2002) Rice phosphate transporters include an evolutionarily divergent gene specifically activated in arbuscular mycorrhizal symbiosis. Proc Natl Acad Sci U S A 99:13324-13329

Petutschnig EK, Jones AM, Serazetdinova L, Lipka U, Lipka V (2010) The lysin motif receptor-like kinase (LysM-RLK) CERK1 is a major chitin-binding protein in Arabidopsis thaliana and subject to chitin-induced phosphorylation. J Biol Chem 285:28902-28911

Pietraszewska-Bogiel A, Lefebvre B, Koini MA, Klaus-Heisen D, Takken FL, Geurts R, Cullimore JV, Gadella TW (2013) Interaction of Medicago truncatula lysin motif receptor-like kinases, NFP and LYK3, produced in Nicotiana benthamiana induces defence-like responses. PLoS One 8, e65055

Recorbet G, Abdallah C, Renaut J, Wipf D, Dumas-Gaudot E (2013) Protein actors sustaining arbuscular mycorrhizal symbiosis: undergorund artists break the silence. New Phytol 199:26-40

Remy W, Taylor TN, Hass H, Kerp H (1994) Four hundred-million-year-old vesicular arbuscular mycorrhizae. Proc Natl Acad Sci U S A 91:11841-11843

Resenders CM, Geil RD, Guinel FC (2001) Mycorrhizal development in a low nodulating pea mutant. New Phytol 150:563-572

Secilia J, Bagyaraj DJ (1992) Selection of efficient vesicular-crbuscular mycorrhizal fungi for wetland rice (Oryza sativa L.). Biol Fertil Soils 13:108-111

Secilia J, Bagyaraj DJ (1994) Selection of efficient vesicular-crbuscular mycorrhizal fungi forwetland rice - a preliminary screen. Mycorrhiza 4:265-268

Shi B, Ni L, Liu Y, Zhang A, Tan M, Jiang M (2014) OsDMl3-mediated activation of OsMPK1 regulates the activities of antioxidant enzymes in abscisic acid signalling in rice. Plant Cell Environ 37:341-352

Shi B, Ni L, Zhang A, Cao J, Zhang H, Qin T, Tan M, Zhang J, Jiang M (2012) OsDMI3 is a novel component of abscisic acid signaling in the induction of antioxidant defense in leaves of rice. Mol Plant 5:1359-1374

Shimizu T, Nakano T, Takamizawa D, Desaki Y, Ishii-Minami N, Nishizawa Y, Minami E, Okada K, Yamane H, Kaku H, Shibuya N (2010) Two LysM receptor molecules, CEBiP and OsCERK1, cooperatively regulate chitin elicitor signaling in rice. Plant J 64:204-214

Shimoda Y, Han L, Yamazaki T, Suzuki R, Hayashi M, Imaizumi-Anraku H (2012) Rhizobial and fungal symbioses show different requirements for calmodulin binding to calcium calmodulin-dependent protein kinase in Lotus japonicus. Plant Cell 24:304-321

Singh S, Katzer K, Lambert J, Cerri M, Parniske M (2014) CYCLOPS, a DNA-binding transcriptional activator, orchestrates symbiotic root nodule development. Cell Host Microbe 15:139-152

Solaiman MZ, Hirata H (1997) Effect of arbuscular mycorrhizal fungi inoculation of rice seedlings at the nursery stage upon performance in the paddy field and greenhouse. Plant and Soil 191:1-12

Solaiman MZ, Hirata H (1998) Glomus-wetland rice mycorrhizas influenced by nursery inoculation techniques under high fertility soil conditions. Biol Fertil Soils 27:92-96

Takeda N, Maekawa T, Hayashi M (2012) Nuclear-localized and deregulated calcium- and calmodulin-dependent protein kinase activates rhizobial and mycorrhizal responses in Lotus japonicus. Plant Cell 24:810-822

Takeda N, Tsuzuki S, Suzaki T, Parniske M, Kawaguchi M (2013) CERBERUS and NSP1 of Lotus japonicus are common symbiosis genes that modulate arbuscular mycorrhiza development. Plant Cell Physiol 54:1711-1723

Umehara M, Hanada A, Yoshida S, Akiyama K, Arite T, Takeda-Kamiya N, Magome H, Kamiya Y, Shirasu K, Yoneyama K, Kyozuka J, Yamaguchi S (2008) Inhibition of shoot branching by new terpenoid plant hormones. Nature 455:195-200
Vallino M, Fiorilli V, Bonfante P (2014) Rice flooding negatively impacts root branching and arbuscular mycorrhizal colonization, but not fungal viability. Plant Cell Environ 37:557-572

Vallino M, Greppi D, Novero M, Bonfante P, Lupotto E (2009) Rice root colonisation by mycorrhizal and endophytic fungi in aerobic soil. Ann Appl Biol 154:195-204

Venkateshwaran M, Cosme A, Han L, Banba M, Satyshur KA, Schleiff E, Parniske M, Imaizumi-Anraku H, Ané J-M (2012) The recent evolution of a symbiotic ion channel in the legume family altered ion conductance and improved functionality in calcium signaling. Plant Cell 24:2528-2545

Wang W, Xie ZP, Staehelin C (2014) Functional analysis of chimeric lysin motif domain receptors mediating Nod factor-induced defense signaling in Arabidopsis thaliana and chitin-induced nodulation signaling in Lotus japonicus. Plant J 78:56-69

Willmann R, Lajunen HM, Erbs G, Newman MA, Kolb D, Tsuda K, Katagiri F, Fliegmann J, Bono JJ, Cullimore JV, Jehle AK, Gotz F, Kulik A, Molinaro A, Lipka V, Gust AA, Nurnberger T (2011) Arabidopsis lysin-motif proteins LYM1 LYM3 CERK1 mediate bacterial peptidoglycan sensing and immunity to bacterial infection. Proc Natl Acad Sci U S A 108:19824-19829

Yang C, Li A, Zhao Y, Zhang Z, Zhu Y, Tan X, Geng S, Guo H, Zhang X, Kang Z, Mao $L$ (2011) Overexpression of a Wheat CCaMK Gene Reduces ABA Sensitivity of Arabidopsis thaliana During Seed Germination and Seedling Growth. Plant Mol Biol Rep 29:681-692

Yang SY, Grønlund M, Jakobsen I, Grotemeyer MS, Rentsch D, Miyao A, Hirochika H, Kumar CS, Sundaresan V, Salamin N, Catausan S, Mattes N, Heuer S, Paszkowski U (2012) Nonredundant regulation of rice arbuscular mycorrhizal symbiosis by two members of the phosphate transporter 1 gene family. Plant Cell 24:4236-4251

Yano K, Yoshida S, Müller J, Singh S, Banba M, Vickers K, Markmann K, White C, Schuller B, Sato S, Asamizu E, Tabata S, Murooka Y, Perry J, Wang TL, Kawaguchi M, Imaizumi-Anraku H, Hayashi M, Parniske M (2008) CYCLOPS, a mediator of symbiotic intracellular accommodation. Proc Natl Acad Sci U S A 105:20540-20545

Yokota K, Soyano T, Kouchi H, Hayashi M (2010) Function of GRAS proteins in root nodule symbiosis is retained in homologs of a non-legume, rice. Plant Cell Physiol 51:1436-1442

Yoshida S, Kameoka H, Tempo M, Akiyama K, Umehara M, Yamaguchi S, Hayash H, Kyozuka J, Shirasu K (2012) The D3 F-box protein is a key component in host strigolactone responses essential for arbuscular mycorrhizal symbiosis. New Phytol 196:1208-1216

Zhang X, Dong W, Sun J, Feng F, Deng Y, He Z, Oldroyd GE, Wang E (2015) The receptor kinase CERK1 has dual functions in symbiosis and immunity signalling. Plant J 81:258-267

Zhang XC, Wu X, Findley S, Wan J, Libault M, Nguyen HT, Cannon SB, Stacey G (2007) Molecular evolution of lysin motif-type receptor-like kinases in plants. Plant Physiol 144:623-636

Zhu H, Riely BK, Burns NJ, Ané J-M (2006) Tracing nonlegume orthologs of legume genes required for nodulation and arbuscular mycorrhizal symbioses. Genetics 172:2491-2499

\section{Submit your manuscript to a SpringerOpen ${ }^{\oplus}$ journal and benefit from:}

- Convenient online submission

- Rigorous peer review

- Immediate publication on acceptance

- Open access: articles freely available online

- High visibility within the field

- Retaining the copyright to your article

Submit your next manuscript at springeropen.com 